University of Nebraska - Lincoln

DigitalCommons@University of Nebraska - Lincoln

Faculty Publications from the Harold W. Manter Laboratory of Parasitology

4-1976

\title{
Prevalence of Antibodies to Toxoplasma gondii in Wild and Domestic Animals of New Mexico, Arizona and Colorado
}

\author{
Alan A, Marchiondo \\ University of New Mexico, alan.marchiondo@tevausa.com \\ Donald W. Duszynski \\ University of New Mexico, eimeria@unm.edu \\ Gary O. Maupin \\ Centers for Disease Control and Prevention
}

Follow this and additional works at: https://digitalcommons.unl.edu/parasitologyfacpubs

Part of the Parasitology Commons

Marchiondo, Alan A,; Duszynski, Donald W.; and Maupin, Gary O., "Prevalence of Antibodies to Toxoplasma gondii in Wild and Domestic Animals of New Mexico, Arizona and Colorado" (1976). Faculty Publications from the Harold W. Manter Laboratory of Parasitology. 123.

https://digitalcommons.unl.edu/parasitologyfacpubs/123

This Article is brought to you for free and open access by the Parasitology, Harold W. Manter Laboratory of at DigitalCommons@University of Nebraska - Lincoln. It has been accepted for inclusion in Faculty Publications from the Harold W. Manter Laboratory of Parasitology by an authorized administrator of DigitalCommons@University of Nebraska - Lincoln. 


\title{
PREVALENCE OF ANTIBODIES TO Toxoplasma gondii IN WILD AND DOMESTIC ANIMALS OF NEW MEXICO, ARIZONA AND COLORADO[]
}

\author{
ALAN A. MARCHIONDO, DONALD W. DUSZYNSKI and GARY O. MAUPIN 2, \\ Department of Biology, The University of New Mexico, Albuquerque, New Mexico 87131, USA
}

Abstract: Using the Sabin-Feldman dye test, sera from wild and domestic animals in New Mexico, Arizona and Colorado were tested for the prevalence of antibodies to Toxoplasma gondii. The prevalence of positive titers $(=1: 8)$ in animals from these areas was: New Mexico (178 of 569, 31\%), Arizona (11 of 56, 20\%), and Colorado ( 2 of $7,29 \%$ ). The overall prevalence of antibodies to Toxoplasma was $30 \%$ (191 of 632).

Nine of 17 fecal samples from wild zoo felines contained Toxoplasma-like oocysts which were inoculated per os and intraperitoneally into mice. Mice from six of these nine inoculations later showed positive dye test titers and tissues from five of these six groups had tissue cysts when examined histologically.

\section{INTRODUCTION}

Results from many serological surveys confirm the widespread prevalence of Toxoplasma gondii antibodies in wild and domestic animals from different areas of the United States, $3,7,0,15-17,19,20,23$ but there are no reports on this subject from New Mexico animals. Our primary effort in this study was to determine the prevalence of Toxoplasma antibodies in wild and domestic animals from New Mexico using the Sabin-Feldman dye test. We also examined fecal material from some cats for oocysts. Cooperation of colleagues added additional information on animals from Arizona and Colorado.

\section{MATERIALS AND METHODS}

Toxoplasma gondii, RH-strain and $\mathrm{M}$ 7741 strain, were obtained from Dr. J. K. Frenkel, Department of Pathology and
Oncology, The University of Kansas Medical Center, Kansas City, Kansas, in two tubes of human lung tissue cells. The $\mathrm{RH}$-strain is maintained in our laboratory by routine intraperitoneal passage twice weekly in outbred (CF-1, Carworth Farms, Portage, Michigan) or inbred (A/J, Jackson Laboratories, Bar Harbor, Maine) adult, albino mice, Mus musculus. We used organisms from this strain in the Sabin-Feldman dye test to detect Toxoplasma antibodies. The M-strain of $T$. gondii was injected subcutaneously into two albino rabbits, Oryctolagus cuniculus, obtained locally. Six hrs after injection, the rabbits were given water and food ad libitum to which $200 \mathrm{mg} / 100 \mathrm{ml}$ and $200 \mathrm{mg} / 100 \mathrm{~g}$, respectively, of sulfadiazine had been added. This was done to establish a chronic infection to provide serum of a known titer as the positive control for the dye test. ${ }^{13}$ Rabbits were

1: Part of a thesis submitted to the Graduate School of the University of New Mexico in partial fulfillment of the recuirements for the Master of Science in Biology. This research was supported, in part, by the Brown-Hazen Fund of Research Corporation, 1290 Bayshore Highway, Burlingame, California, 94010; in part, by the Sandia University Research Program (SURP) through Sandia Cornoration, Albuquerque, New Mexico; and, in part, by a University of New Mexico Research Allocations Grant-In-Aid.

2 Present address: CDC, Colorado State University, Fort Collins, Colorado, 80523, USA. 
bled via the marginal ear vein and their sera were used as the positive control in the dye test. A $0.1 \mathrm{ml}$ aliquot of mouse peritoneal exudate containing living Toxoplasma organisms (RH-strain) plus accessory factor was used as the negative control. ${ }^{11}$ Accessory factor is a heat-labile substance present in normal human serum and was obtained via venipuncture from persons not demonstrating Toxoplasma antibodies or the hostility factor. ${ }^{2,21}$ Accessory factor was frozen in 5 to $7 \mathrm{ml}$ quantities at $-20 \mathrm{C}$ and stored at -70 $\mathrm{C}$ in dry ice.

\section{Blood samples and the dye test}

Blood samples were collected in vacutainer tubes or absorbed onto filter paper discs (tabs)..$^{23}$ Whole blood samples were allowed to clot at ambient temperature for $1 \mathrm{hr}$, centrifuged at $450 \mathrm{xg}$ for $15 \mathrm{~min}$, and then stored at $-20 \mathrm{C}$ until they could be tested. When tabs were used, two tabs were soaked in blood from each host and then air dried. They were stored at 3 to 5 $\mathrm{C}$ and prepared for the dye test as described by Wallace. ${ }^{23}$ This method saves time and storage space; however, the lowest possible titer obtainable is $1: 32$, compared to $1: 2$ using whole serum. All sera were inactivated at $56 \mathrm{C}$ for $30 \mathrm{~min}$ and antibodies were determined by the SabinFeldman dye test $\mathrm{t}^{2 \mathrm{1}}$ as modified by Frenkel and Jacobsit and by Frenkel (personal communication). Two-fold serum dilutions were prepared, and final dilutions of $1: 2,1: 8,1: 32,1: 128,1: 512$ and $1: 2048$ were tested and observed. Positive titers $\geqslant 1: 8$ are regarded as significant ${ }^{8}$ and were considered by us to represent previous or current infection.

\section{Fecal examination}

Feces were placed in $3 \%$ aqueous $(\mathrm{w} / \mathrm{v})$ potassium dichromate $\left(\mathrm{K}_{2} \mathrm{Cr}_{2} \mathrm{O}_{i}\right)$ and maintained at room temperature (20$22 \mathrm{C}$ ) for 4 to 5 days. This material was then processed as described elsewhere to search for oocysts. ${ }^{6}$ Examinations of processed samples were made with a Zeiss photomicroscope equipped with $100 \mathrm{X}$ achromatic and apochromatic oil immersion objectives and measurements were made with an ocular micrometer.

\section{Demonstration of Toxoplasma oocysts in fecal samples}

Toxoplasma oocysts are small (10-12 $\mu \mathrm{m})$ and if present in small numbers can be overlooked in cat feces. If cleaned particulate material with oocysts is inoculated into mice the parasite may reproduce extensively in the tissues if oocyst infectivity has not been altered by $\mathrm{K}_{2} \mathrm{Cr}_{2} \mathrm{O}_{7}{ }^{4}$ Tissue cysts and either chronic or acute infections may then result and demonstrate the presence of Toxoplasma in fecal samples in which oocysts were overlooked. The possible presence of Toxoplasma oocysts in fecal samples from eight wild and two zoo-kept cats was examined by inoculation into mice either orally or intraperitoneally (IP) as outlined by Dubey et al..$^{5}$ and Miller et al..$^{18}$ One of the wild feline samples was from New Mexico and seven were from Montana. These wild felines are strictly carnivorous on rodents, deer, mountain sheep and antelope as well as smaller domestic stock. such as sheep and goats. ${ }^{1}$ Two samples were from cheetahs in the Albuquerque Zoo, Albuquerque, New Mexico. These animals were wild-caught, but have been fed mostly on zupreem (Hills Division of Riviana Foods, P.O. Box 148, Topeka, Kansas), while in captivity.

\section{Examination of mice for Toxoplasma}

Mice inoculated with feline feces were bled 14 days postinoculation and examined for Toxoplasma antibody by the dye test. Serological examination 14 days post-inoculation is sufficient; however, Frenkel (personal communication) suggests that 16 to 20 days is a little safer. ${ }^{5}$ Mice that died soon after inoculation as well as those surviving were necropsied. Impression smears of brain, peritoneal exudate, lungs, liver, spleen, heart and mesenteric lymph nodes were prepared and examined after staining with Giemsa. If no organisms were found, paraffin sections of brain, kidney, liver, lungs, spleen, heart and mesenteric lymph nodes were prepared, stained with hematoxylin- 
TABLE 1. Prevalence of antibody titers $(\supseteq 1: 8 \text { and } \supseteq 1: 32)^{1}$ to Toxoplasma gondii in the sera of wild and domestic animals from New Mexico, Arizona, and Colorado as determined by the Sabin-Feldman Dye Test.

\begin{tabular}{|c|c|c|c|c|}
\hline \multirow[b]{2}{*}{ Host Location/Species Tested } & \multicolumn{2}{|c|}{ No. Tested } & \multirow{2}{*}{$\begin{array}{l}\text { No. } \\
\text { Positive }\end{array}$} & \multirow{2}{*}{$\begin{array}{c}\% \\
\text { Positive }\end{array}$} \\
\hline & Whole sera & Tabs & & \\
\hline
\end{tabular}

New Mexico

Wild Animals

Carnivores

Badgers (Taxidea taxus)

Bobcats (Lynx rufus)

Dogs (Canis familiaris) ${ }^{2}$

233

Mountain Lions (Felis concolor)

\begin{tabular}{|c|c|c|c|}
\hline \multirow{4}{*}{233} & 17 & 3 & 18 \\
\hline & 27 & 12 & 44 \\
\hline & & 111 & 48 \\
\hline & 2 & 0 & 0 \\
\hline \multirow{8}{*}{233} & $\bar{T}$ & & $\overline{15}$ \\
\hline & 46 & 126 & 45 \\
\hline & 1 & 1 & 100 \\
\hline & 10 & 2 & 20 \\
\hline & 10 & 2 & 20 \\
\hline & 42 & 8 & 19 \\
\hline & - & - & - \\
\hline & 63 & 13 & 21 \\
\hline
\end{tabular}

Herbivores

Omnivores

Coyotes (Canis latrans)

Grey Foxes (Urocyon cinereargenteus)

Hog-Nosed skunk (Conepatus mesoleucus)

Kit fox (Vulpes marcotis)

Striped skunk (Mephitis mephitis)

00

Cotton-Tail Rabbit (Sylvilagus sp.)

Jackrabbit (Lepus californicus)

Porcupine (Erethrizon dorsatum)

20

Rodents (other than Porcupines)

19

21

Domestic/Lab Animals

Cats $(F$. domesticus)

Dogs ( $C$. familiaris)

Rhesus monkeys (Macaca mulatta) 29

\begin{tabular}{rrr}
87 & 23 & 26 \\
9 & 3 & 33 \\
1 & 1 & 100 \\
1 & 1 & 100 \\
5 & 1 & 20 \\
\hline 103 & -29 & -28
\end{tabular}

- 29

$\begin{array}{lll}91 & 7 & 8\end{array}$

$\begin{array}{lll}4 & 3 & 75\end{array}$

$0 \quad 0$

$\begin{array}{llll}29 & \overline{95} & \overline{10} & 8\end{array}$

Arizona

Wild Animals

Bobcat (L. rufus)

Coyotes ( $C$. latrans)

Dogs (C. familiaris $)^{2}$

50

100

$\begin{array}{lll}5 & 1 & 20\end{array}$

1020

Colorado

$\begin{array}{llll}50 & - & - & 11\end{array}$

Wild Animals

\begin{tabular}{lrrrr} 
Dogs $(C \text { familiaris })^{2}$ & 7 & 2 & 29 \\
\hline TOTALS & 319 & 313 & 191 & 30 \\
\hline
\end{tabular}

${ }^{1}$ Whole sera samples of $\supseteq 1: 8$ and tab samples of $\supseteq 1: 32$ are considered significant.

${ }^{2}$ Feral dogs sampled on Indian reservations. 


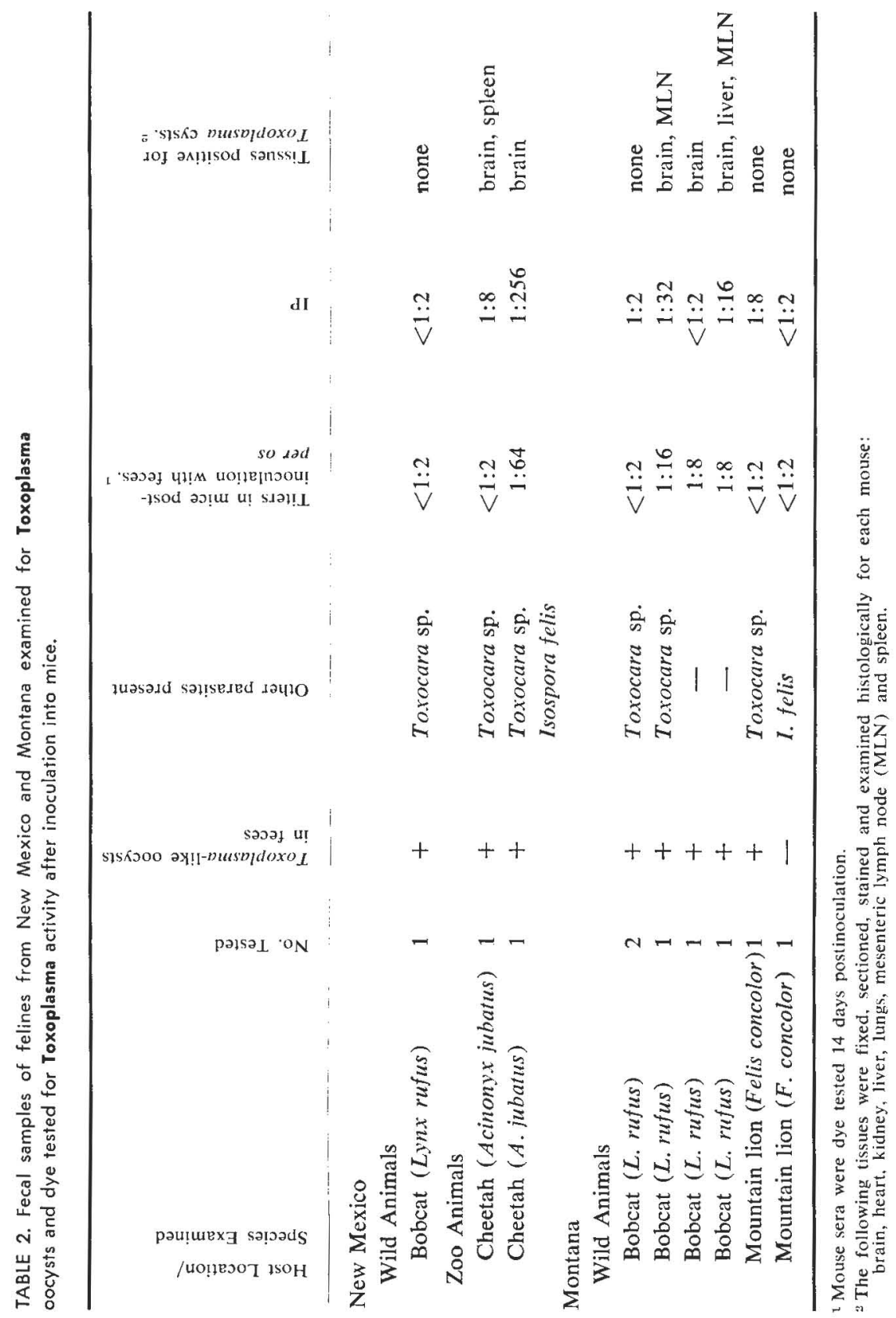


eosin and periodic acid Schiff's-hematoxylin (PASH), and examined with the light microscope.

\section{RESULTS}

\section{Serology}

Sera from all animals were tested for antibodies to $T$. gondii by the SabinFeldman dye test and the overall prevalence was $30 \%$ (191 of 632, Table 1 ). Of 445 wild animals tested from New Mexico, $45 \%$ of the carnivores, $21 \%$ of the herbivores, and $28 \%$ of the omnivores were seropositive (titers $\geq 1: 8$ or $\supseteq 1: 32$ ). Feral dogs, often found in packs on Indian reservations, had a low $(20 \%)$, intermediate $(29 \%)$, and high (48\%) prevalence of infection in Arizona, Colorado and New Mexico, respectively. A titer of $\geq 1: 8$ is considered to be significant in humans ${ }^{5}$ and we used this value as our lowest endpoint for positive titers (Table 1). However, we have little information as to the significance of $1: 8$ in the animals we tested. Thirty-two of the animals we tested had titers of $1: 2$ or $1: 4$ and these are not included in our results (Table 1). These values would change the percent prevalence in Table 1 as follows: dogs from New Mexico Indian reservations $55 \%$ ( 128 of 233 ), dogs from Arizona Indian reservations $48 \%$ (24 of 50 ) and coyotes from Arizona $40 \%$ ( 2 of 5). All 29 primates tested, whether wildcaught or laboratory-adapted, were negative.

\section{Fecal samples}

Feces from 9 bobcats, 5 mountain lions, 2 cheetahs, and 1 bengal tiger were examined for oocysts. Portions of 10 of these samples, nine of which had oocysts similar to those described for $T$. gondii, were inoculated into mice (Table 2). Mice from six of these nine inoculations later showed positive dye test titers and tissues from five of these six groups had tissue cysts when examined histologically.

\section{DISCUSSION}

Only species of the cat family (Felidae) are capable of producing oocysts. ${ }^{12}$. ${ }^{14,1 \mathrm{~s}}$ If sporulated oocysts are ingested, Toxoplasma infection may result in humans and other animals. The majority of Toxoplasma infections are asymptomatic with immunity resulting in the formation of tissue cysts which can transfer the infection if ingested by carnivores or cannibals. Yilmaz and Hopkins ${ }^{24}$ showed that oocysts remain infective up to 334 days in potted, shaded and moist soil and Frenkel and Dubey ${ }^{10}$ found drying moderately deleterious to oocysts in cat feces. Thus the semi-arid environment of New Mexico should be relatively hostile to oocysts and result in a lower prevalence than would occur in animals living in more humid surroundings. When comparing the prevalence of domestic (=household) cats from New Mexico (Table 1) to the prevalence in domestic cats from Missouri and Iowa $(38 \%)$, North Dakota $(45 \%)$ and the region around Memphis, Tennessee $(49 \%$ to $57 \%)$, the idea of higher prevalence in more hot and humid areas of the United States is supported. ${ }^{3}$ $7,15,17$

Transmission to non-carnivores such as rabbits and some rodents requires ingestion of the oocyst stage. On the other hand, although carnivorous and omnivorous animals may become infected by ingesting oocysts, it is more probable that Toxoplasma has become incorporated into the natural food chain, and smaller animals become vectors of Toxoplasma infection to predators such as bobcats, coyotes, foxes and badgers. The prevalence figures given (Table 1) support the view that such cyclical carnivorism is responsible for a major part of the transmission of toxoplasmosis in New Mexico, whereas oocyst shedding is apparently of lesser importance. Therefore, these results are consistent with the views that animals with persisting cysts are the main source of infection for carnivores. ${ }^{3,18}$ 


\section{Acknowledgements}

We wish to thank Dr. J. K. Frenkel for the T. gondii strains, for his assistance and encouragement throughout this study, and for his critical review of the manuscrint during its preparation. We are indebted to Dr. David E. Worley, Montana State University, Bozeman, for collecting fecal material from wild felines. Thanks are also due Mr. Neil Weber, New Mexico Environmental Improvement Agency, Santa Fe; Mr. Gerald Gates, New Mexico Denartment of Game and Fish, Santa Fe; Mr. C. D. Cunningham, New Mexico Denartment of Game and Fish, Albuquerque; Mr. Edwin Moore, Public Health Service Indian Hospital, Albuguerque; Dr. G. I. Goldschmidt, Mr. Billy J. Smith, Mr. Mathew Solomon, and Mr. Woody Begay, Office of Environmental Health, Indian Health Service, Window Rock, Arizona, for supplying the blood samples used in this study.

\section{LITERATURE CITED}

1. BERGHOFER, L. 1967. Predators. New Mexico Wildlife Management, New Mexico Department of Game and Fish, Santa Fe, New Mexico. pp. 195-199.

2. DESMONTS, G. 1955. Sur la technique de l'épreuve de lyse des toxoplasmes. La Semaine des Hopitaux de Paris. 31: 1-6.

3. DUBEY, J. P. 1973. Feline toxoplasmosis and coccidiosis: A survey of domiciled and stray cats. J. Amer, vet. med. Ass. 162: 873-877.

4. DUbEY, J. P., N. L. MILLER and J. K. FRENKEL. 1970. The Toxoplasma gondii oocyst from cat feces. J. Exp. Med. 132: 636-662.

5. DUBEY, J. P., S. W. SWAN and J. K. FRENKEL. 1972. A simplified method for isolation of Toxoplasma gondii from the feces of cats. J. Parasit. 58: 1005-1006.

6. DUSZYNSKI, D. W. 1972. Host and parasite interactions during single and concurrent infections with Eimeria nieschulzi and E. separata in the rat. J. Protozool. 19: 82-88.

7. EYLES, D. E., C. L. GIBSON, N. COLEMAN, C. S. SMITH, J. R. JUMPER and F. E. JONES. 1959. The prevalence of toxoplasmosis in wild and domestic animals in the Memphis region. Amer. J. Trop. Med. 8: 505-510.

8. FELDMAN, H. A. 1968. Toxoplasmosis. N. Eng. J. Med. 229: 2431-2437.

9. FELDMAN, H. A. and L. T. MILLER. 1956. Serological study of toxoplasmosis prevalence. Amer. J. Hyg. 64: 320-335.

10. FRENKEL, J. K. and J. P. DUBEY. 1972. Toxoplasmosis and its prevention in cats and man. J. Inf. Dis. 126: 664-673.

11. FRENKEL, J. K. and L. JACOBS. 1958. Ocular toxoplasmosis: Pathogenesis, diagnosis, and treatment. Am. Med. Ass. Arch. Ophthal. 59: 260-279.

12. FRENKEL, J. K., J. P. DUBEY and N. L. MILLER. 1970. Toxoplasma gondii: Fecal stages identified as coccidian oocysts. Science 167: 893-896.

13. FRENKEL, J. K., R. W. WEBER and M. N. LUNDE. 1960. Acute toxoplasmosis. Effective treatment with pyrimethamine, sulfadiazine, leucovorin, calcium and yeast. J. Amer. Med. Assoc. 173: 1471-1476.

14. JEWELL, M. L., J. K. FRENKEL, J. K. JOHNSON, K. M. REED and A. RUIZ. 1972. Development of Toxoplasma oocysts in neotropical Felidae. Am. J. Trop. Med. 21: 512-517.

15. JONES, F. E., D. E. EYLES and C. L. GIBSON. 1957. The prevalence of toxoplasmosis in the domestic cat. Amer. J. Trop. Med. 6: 820-826.

16. McCULLOCH, W. F., B. G. FOSTER and J. L. BRAUN. 1964. Serological survey of toxoplasmosis in Iowa domestic animals. J. Amer. vet. med. Assoc. $144: 272-275$. 
17. McILWAIN, P. K. 1969. Prevalence of antibodies to Toxoplasma gondii in domestic animals of North Dakota. Arch. Environ. Health 19: 885-886.

18. MILIER, N. L., J. K. FRENKEL and J. P. DUBEY. 1972. Oral infections with Toxoplasma cysts and oocysts in felines, other mammals, and in birds. J. Parasit. 58: 928-937.

19. RIEMANN, H. P., M. E. FOWLER, T. SCHULTZ, A. LOCK, J. THILSTED, L. T. PULLEY, R. V. HENDRICKSON, A. M. HENNESS, C. E. FRANTI and D. E. BEHYMER. 1974. Toxoplasmosis in Pallas cats. J. WildI. Dis. $10: 471-477$.

20. RIEMANN, H. P., J. A. HOWARTH, R. RUPPANNER, C. E. FRANTI and D. E. BEHYMER. 1975. Toxoplasma antibodies among bobcats and other carnivores of Northern California. J. Wildl. Dis. 11: 272-276.

21. SABIN, A. B. and H. A. FELDMAN. 1948. Dye as microchemical indicators of a new immunity phenomenon affecting a protozoan parasite (Toxoplasma). Science 108: 660-663.

22. VANDERWAGEN, L. C., D. E. BEHYMER, H. P. RIEMANN and C. E. FRANTI. 1974. A survey for Toxoplasma antibodies in Northern California livestock and dogs. J. Amer, vet. med. Ass. 164: 1034-1037.

23. WALlACE, G. D. 1969. Sabin-Feldman dye test for toxoplasmosis. Amer. J. Trop. Med. and Hyg. 18: 395-398.

24. YILMAZ, S. M. and S. H. HOPKINS. 1972. Effects of different conditions on duration of infectivity of Toxoplasma gondii oocysts. J. Parasit. 58: 938939. 